\title{
信託活用と公的補助によるマンション建替えに関する基礎的研究 \\ 一所有から利用への転換 - \\ BASIC STUDY OF HOW TO REBUILD A CONDOMINIUM USING THE TRUST WITH PUBLIC SUBSIDES
}

- Converting from the ownership to the use -

$$
\begin{aligned}
& \text { 辻 壽 一*, 馬場麻衣** } \\
& \text { Toshikazu TSUJI and Mai BABA }
\end{aligned}
$$

\begin{abstract}
In order to get the consensus for rebuilding a condominium, it will be most important to reduce the amount of the burden of the construction cost. However, the current Condominium Ownership Law shows it were likely to take the assets away from a division owner who object to that project by the decision of majority. This study is to study about the reconstructing system of a condominium without so much burden for the division owner, under the population decline society, by establishing the general incorporated association as a civil trust organization.
\end{abstract}

Keywords : Condominium, Rebuilding, Trust, Housing systems, Sustainable, Public subsidies マンション，建替え，信託，住宅システム，持続可能，公的支援

\section{1. はじめに}

\section{1 研究の背景と目的}

2013 年末における日本の分譲マンション戸数は約 601 万戸で、 総住宅ストック数約 6,063 万戸の $9.9 \%$ にる。都市部ではさらに その割合が高く、マンションは重要な住まいの形として定着してき た。一方、1980 年以前に建設されたマンションは約 95 万戸で、そ の老朽化も進んでいる。

社会資本としてのマンションを長期的に維持・管理・使用するこ とは当然重要であるが、いつか建替えの時期を迎えることも事実で ある。そして、従来のマンション建替えは、概ね建替え後に増加す る住戸の売却益を建替え費用にあてるという手法がとられてきた。 しかし、これからの人口減少社会を展望すると、今後ともこの手法 が活用できるとは考えにくい。また、一般の民間分譲マンションの 多くは、当初から容積率を最大限に使って建設されているため、建 替えの際、保留床を得ることは基本的に困難である。したがって、 国も 2014 年に「マンションの建替えの円滑化等に関する法律」を 改正し、耐震性に劣る老朽マンションの建替えだけではなく、その 除却も推進する敷地売却制度等の施策を導入している。

一般的に、マンションの建替えには多額の費用負担が発生する。 したがって、建替えの合意形成を円滑に進めるためには、建替え費 用の負担軽減をはかる方策が重要と考えられる。実際、「優良建築物 等整備事業(マンション建替タイプ)」等の施策によって、マンショ ンの建替え支援を目的と寸る公的補助も行われている。

* 大阪樟荃女子大学 教授 ·博士 $($ 学術 $)$

** 北海道立総合研究機構北方建築総合研究所 研究職員 - 博士 (工学)
また、従来の住戸数を増加させる建替え手法の場合、従前の豊か なオープンスペースと景観を棄損して建替えられる場合が数多くあ った。マンションの敷地・建物環境が都市に与える影響は、戸建て 住宅と比較にならないほど大きくなっている。人口減少時代を迎え、 将来の空き家問題も勘案すると、住戸数もほぼ従前と同数で建替え ることができ、豊かな緑地等のオープンスペースを極力壊さない建 替え方策が必要だといえる。

本研究は、居住者の負担軽減を図るため、不動産信託と公的資金 を活用し、従前区分所有者を社員とする非営利型一般社団法人注 1) を民事信託の受託者として、おおよそ建替え前と同じ住戸数でマン ションを建替える方策の可能性を探ることを目的としている。

\section{2 既往の研究}

既往研究において、公益信託、農地信託制度や土地信託制度に関 する論文はあるが、マンションの建替えと不動産信託との関係を考 察した研究はあまり見られない。また、2004 年 12 月に「信託業法」 が、2007 年 9 月に「信託法」が抜本的に改正されている。この改 正で、金融機関以外の事業者が信託制度を利用することが可能とな る等、従来と大きく変わる法整備がなされているため、法改正を踏 まえた既往研究の考察が必要といえる。

齋藤 ${ }^{1)}$ は、不動産信託を使ったマンションの分譲手法や修繥積立 金等の管理組合財産の信託活用について詳細に検討している。また 齋藤は、新たな信託類型の活用可能性について論じているが、管理

Prof., Osaka Shoin Women's University, Ph.D.

Researcher, Hokkaido Research Organization, Dr.Eng. 
組合が法人化して信託の受託者となることには言及していない。

鎌野 ${ }^{2)}$ はマンションの建替えとして信託的手法の導入を検討して いる。ただ、鎌野が提案する建替えは第三者を受託者とし、その再 生資金において建替え費用に笨する区分所有者一の対応を、建替え 後の増床分の分譲対価による拠出金で賄うとするもので、建替え後 の住戸数の増加を前提としている。

したがって、本研究の区分所有者自身が非営利型の一般社団法人 を設立し、ほほ従前と同数の住戸数でマンションを建替え、さらに、 建物完成後に建物の所有権から利用権へと転換するという、信託を 活用寸るマンション建替えは新規性が高いものと考える。

\section{2. 現在までのマンション建替え手法とその現状と課題}

2. 1 マンション建替えの手法

マンションの建替え手法として、現在、次の 3 種類がある。

\section{1 ） 区分所有者の全員合意による建替え}

区分所有法は 1962 年 4 月に制定されたが、1983 年 5 月に区分所 有法が改正されるまで、マンションを建替える場合は区分所有者全 員の合意が必要であった。

\section{2 ) 区分所有者の建替え決議による建替え}

1983 年の区分所有法改正で建替え決議制度が導入され、費用の過 分性などの建替え決議要件がありつつも、区分所有者及び議決権の 5 分の 4 以上の多数決で建替えが可能となった。その後、阪神・淡 路大震災における被災マンションの教訓を受け、2002 年 12 月の区 分所有法改正で建替え要件が撤廃され、区分所有者及び議決権の 5 分の 4 以上の決議のみで建替えが可能となった。

\section{3 )「マンション建替え円滑化法」による建替え}

2002 年 6 月に制定された「マンションの建替えの円滑化等に関 する法律」(以下、「円滑化法」という。一部改正施行 : 2003 年 6 月、2014 年 12 月）による建替え事業で、マンション建替え組合を 設立し、法人として融資や工事契約の締結、区分所有者一括の権利 変換手続きを可能と寸るものである。さらに、老朽マンションの建 替え事業が進まないこともあって、2014 年 6 月に改正施行された 円滑化法において、敷地売却制度が導入された。

これは、耐震性能が不足する「要除却認定マンション」として、 都道府県知事に認定されたマンションについては、区分所有者の 5 分の 4 以上の賛成で敷地売却が決議され、さらに売却・開発を促す ため、建替えにあたって容積率の緩和規定が設けられた。容積率を 緩和寸ることで建替え費用における区分所有者の負担軽減や住戸面 積の拡張、さらに敷地に付加価值を設けて敷地を売却しやすくする ための環境整備といえる。

\section{2 マンション建替えの現状と課題}

マンション再生協議会 ${ }^{3)}$ のホームページからの資料で、まず、 2015 年 4 月現在における円滑法以外の建替え竣工・工事中の事例 から完成済みが 149 事例、事業中が 6 事例の計 155 事例、また、円 滑法による建替え事例から権利变換計画が認可されたものが 67 事 例あった。

円滑化法以外の建替えにおいて、建替え後の住戸数は、全事例の 合計で従前 12,372 戸から建替え後 23,788 戸となり、住戸増加率の 全体平均は 1.92 倍である。増加率 $1.6 \sim 1.8$ 倍未満が 25 事例で最も
多く、1.2 1.4 倍未満が 24 事例、 3 倍以上も 20 事例あった。 1 倍 以下の建替え事例は 18 件 $(12 \%)$ で、これを含む 1.2 倍未満の増 加では 21 事例と全体の $14 \%$ にとどまっている（図 1)。

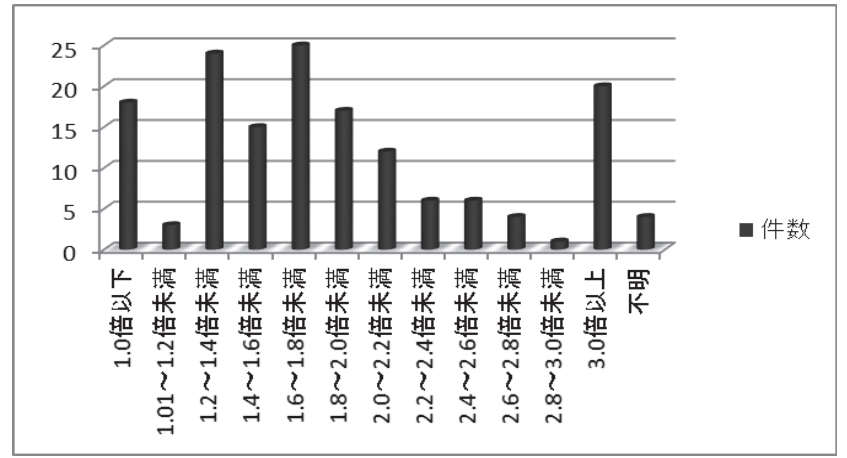

図 1 円滑化法以外の建替え件数と住戸数の増加率

次に、円滑化法による建替えでの建替え後の住戸数は、全事例の 合計で従前 5,733 戸から建替え後 9,988 戸と、住戸増加率の全体平 均は 1.74 倍であった。住戸増加率が 1.8 2.0 倍未満が 11 事例で最 も多く、次に 1.0 倍以下が 9 事例、1.4 から 1.6 倍未満が 8 事例と 続き、住戸増加率 1 倍以下の建替え事例を含む 1.2 倍未満の増加は 14 事例で全体の 20\%であった（図 2)。

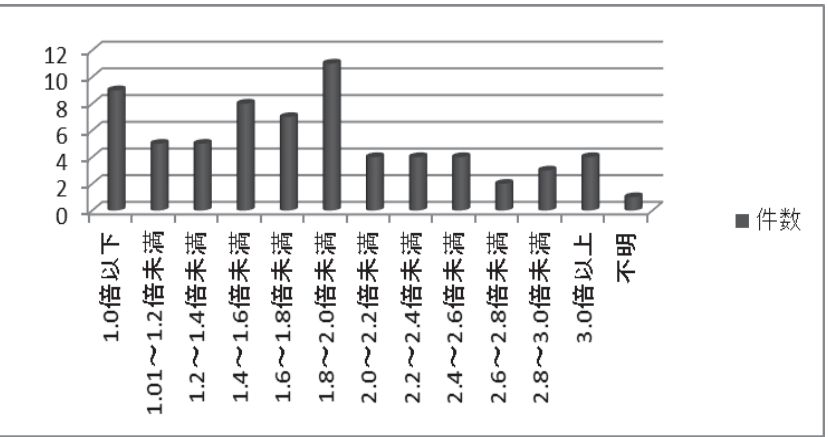

図 2 円滑化法による建替え件数と住戸数の増加率

円滑化法以外による建替えで、建替え後の住戸数の増加率が 1.2 倍未満のものは 21 事例あるが、住戸数の増加が少ない事例には特 殊な要因によるものが多くあった。

\section{1)「東京都港区 泰地六本木マンション」}

従前住戸数 114 戸から建替え後は 7 戸と大きく減少している。こ のマンションは、森ビルが開発した六本木ヒルズに隣接する敷地で、 「泰地六本木マンション」とその南側にあった「泰地六本木ビル」 と合わせて、森ビルが複合商業施設として開発したものである。

\section{2 )「東京都新宿区 同潤会青山アパート」}

複合商業施設として建替えられたもので、建替え後の住戸数は大 幅に減少している。

\section{3)「東京都新宿区 同潤会江戸川アパート」}

建替え後の住戸数は 258 戸から 232 戸へと約 9 割程度に減少して いる。ただし、床面積は $12,316.54 \mathrm{~m}^{2}$ から $20,211.71 \mathrm{~m}^{2}$ へと、約 1.6 倍増加し、住戸専有面積も従前の約 $9 \mathrm{~m}^{2}$ 〜約 $99 \mathrm{~m}^{2}$ から $22.30 \mathrm{~m}^{2}$ 〜 $121.20 \mathrm{~m}^{2}$ へと約 2.2 倍から 1.22 倍程度増加している。余剩容積を 
活用して、住宅の資産価值を大きく向上させた事例といえる。

4 )「東京都中央区 グランドステージ茅場町」

建替え前と建替え後の住戸数に変化がなく 36 戸であった。ただ この建替えは、従前マンションの完成後数ケ月で耐震偽装が発覚し

た、耐震偽装の被害を受けたマンションの建替えである。

この事例では、建築規制によって現在の敷地において従前の床面 積を確保できないことが明らかとなった。そのため、東京都中央区 が当該マンションに隣接寸る（株）内田洋行に働きかけ、内田洋行 の自社ビルと「グランドステージ茅場町」を共同ビルとする建替え を要請した。最終的に、市街地再開発事業として住宅と事務所の複 合ビルとして建替えられている。国、自治体からの建替え支援はあ ったが、住民は 2 重ローンを余儀なくされている。

次に、円滑化法による建替えにおいて、住戸数の増加が 1.2 倍末 満の主なものを考察する。

\section{1)「神奈川県川崎市川崎市大島 4 丁目店舗・市営大島住宅」}

市営住宅と区分所有店舗が混在した敷地・建物の建替えで、国の

補助金を受けた優良建築物等整備事業として行われた。

\section{2 )「東京都町田市 クレストフォルム南町田」}

建替え後の住戸数は同じ 23 戸で、各住戸専有面積もほとんど増 加していない。築 10 年程度のマンションで、都市計画道路の拡張 に伴う補償による建替えである。

\section{3)「神奈川県川崎市川崎駅北口地区第二街区 10 番地地区」}

「京浜駅前共同ビル」、波田野中村ビル」、隣接施行 2 敷地」の 4 つの敷地で、国の補助金を受ける優良建築物等整備事業としての 建替えで、商業、業務、共同住宅の複合施設である。従前住戸数は 20 戸から建替え後は 5 戸に減じている。住戸専有面積は、従前の $33 \mathrm{~m}^{2} \sim 52.37 \mathrm{~m}^{2}$ から約 $50 \mathrm{~m}^{2}$ 〜約 $81 \mathrm{~m}^{2}$ に増加している。

\section{4 ）「埼玉県上尾市 上尾スカイマンション」}

区画整理事業との同時施行であり、各住戸専有面積は約 $58 \mathrm{~m}^{2}$ か ら約 $57 \mathrm{~m}^{2}$ と微減している。

\section{5 ）「埼玉県大宮市 大宮スカイハイツ」}

敷地の一部が都市計画道路にかかるため、用地買収による建替え である。建替え後の住戸専有面積も微増にとどまっている。

\section{6 )「千葉県千葉市稲毛台住宅」}

建替え後の住戸数は、従前の 240 戸から 249 戸の微増であるもの の、建物全体の床面積は従前の $11,136.4 \mathrm{~m}^{2}$ から約 $23,294 \mathrm{~m}^{2}$ と倍以 上となっている。各住戸専有面積は、従前の約 $35 \mathrm{~m}^{2}$ から平均で 80.31 $\mathrm{m}^{2}$ と約 2.3 倍に増加した。分譲マンションとしての資産価值が大き く増加した事例といえる。

以上から、建替え後の住戸数の増加が少ない事例は、優良建築物 等整備事業等の複合商業施設での建替え、震災による建替え、容積 率における既存不適格で敷地面積を増加させた建替え、計画道路に おける移転補償での建替え事業、土地区画整理事業によるもの、余 剩容積を利用して狭小な住戸を拡張することで資産価值を向上させ たものなど、特殊な要因による建替えが数多く含まれている。

いずれにしても、建替え成功事例においては、かなりの容積率余 剩分があって建替えが実現したものが多いといえる。

ただ、容積率の余剩を活用した建替えは、基本的に 1 回限りの方 法であり、同じ手法での再建替えは基本的に困難となる。

また、建替えを必要とする高経年マンションの区分所有者には概
ね高齢者が多いと推測できる。高齢の区分所有者にとって、マンシ ヨンの建替えで過大な費用を負担することは、費用負担と建替え後 の居住年数や建物寿命を勘案すれば、あまり合理的であるとはいえ ない。そしてまた、多数決による建替えは、住まいという社会生活 の基盤を失う区分所有者が生れる可能性も高い。したがって、高齢 者や建替え費用負担が困難な区分所有者にとっても合意しやすいマ ンションの建替え方策の検討がこれからの大きな課題だといえる。

\section{3. 不動産信託によるマンション建替え \\ 3.1 不動産信託とは}

2004 年 12 月に改正された「信託業法」及び 2007 年 9 月の「改 正信託法」によって信託の環境が大幅に改善された。信託法第 2 条 で、信託とは「特定の者が一定の目的（専らその者の利益を図る目 的を除く。同条において同じ。）に従い財産の管理又は処分及びその 他の当該目的の達成のために必要な行為をすべきものとすること」 と定められている。

つまり、信託契約によって、明確な目的をもって財産を託し（委 託者)、託されたもの（受託者）はその財産の管理や処分、また、目 的を達成するための必要な行為を行うことができる、というもので ある。そして、信託する財産は「信託財産」、その運用収益から得る 配当等の権利（受益権）を持つ人を「受益者」とされている。

信託の種類としては、(1)契約による方法、(2)遺言による方法、(3) 一定の意思表示による方法（信託法）があるが、上記のような信託 は、一般的に(1)の契約によって行われる。

不動産を信託財産と寸る信託が不動産信託で、土地や建物所有権、 区分所有権、借地権、借家権なども信託財産とすることが可能で、 マンションの建替えにも不動産信託を活用できるようになった。

主な信託の独自的機能としては、以下のものがある。

\section{1 ) 財産の長期的管理機能としての「意思凍結機能」}

「信託設定当時における委託者の意思を、委託者の意思能力喪失 や死亡という主観的事情（個人的事情）の変化に抗して、長期間に わたって維持するという機能」4)である。

この意思凍結機能によって、委託者の死亡などにかかわらず、長 期にわたって信託行為に定めた委託者の意思（信託の目的、信託財 産の管理方法、受益者への給付方法等）により、受託者に信託行為 を行わせることができる。

\section{2 ）財産の集団的管理機能}

「不特定多数の委託者から拠出された財産を、1つのまとまった 集団として、・・(中略) ・・複数委託者の信託財産に対寸る一括的な 管理・運用という機能」4) が集団的管理機能とされている。これに よって、財産の管理・運用を受託者に一元化することが可能となる。

\section{3 ) 倒産隔離機能}

「信託財産は、そもそも制度上、委託者から受託者に名義が移転 するとともに、受託者の固有財産からも分別管理され・・(中略) - · 受託者個人の債権者は信託財産への強制執行をおこなうことはでき ないし・・(中略) ・・受託者が破産した場合であっても、信託とし ての対抗要件が具備されている限り、信託財産はその破産財団には 組み入れられ」4）ることがなく、信託財産は保全される。

以上の信託の機能は、マンションの建替え工事だけではなく、そ の維持管理面においても有効なものと考えられている。 


\subsection{1 マンション建替えにおける公的支援の現状}

マンションは、多くの居住者が協力しながら居住する共同住宅で あり、その健全な運営は社会の安定に沿うものである。また行政に よる公共インフラ設備の投資についても、マンションの場合、戸建 て住宅と比較して、低いコストに抑えることができる。たとえば大 規模団地の場合を考えると、1 住戸当たりの固定資産税などは戸建 て住宅とあまり差異はないが、団地内道路や上下水道配管の設置・ 維持管理は行政ではなく、団地管理組合によって行なわれている。 したがって、マンションの健全な運営は行政にとっても重要で、そ のための様々な支援策がとられている。そして、マンションの建替 えを支援する主な制度 ${ }^{5)}$ としては、以下のものがある。

\section{1) 優良建築物等整備事業 (マンション建替タイプ)}

「土地の利用の共同化、高度化等に寄与する優良建築物等の整備 を行う事業」における費用に対し、助成が行われる。助成の対象と なる地域は、大都市圈以外に「地方拠点法に基づき指定された地方 拠点都市地域」や「中心市街地活性化法に基づく基本計画に定める 中心市街地」、「人 5 万人以上の市の区域」等が定められている。

また基礎事業要件として、「地区の面積が概ね $1,000 \mathrm{~m}^{2}$ 以上であ ること(三大都市圈等は概ね $500 \mathrm{~m}^{2}$ 以上) 、「空地面積が法定空地率 $+10 \%$ 以上、「整備される建築物が、原則地上 3 階以上で耐火建築 物又は準耐火建築物であること」とされている。補助対象となるも のは建替え決議の前後で異なり、建替え決議の前では測量費や権利 調查及び調整などの調查設計計画費に対する補助の限度額が 741 千 円/戸（1 棟当り住戸数が 50 戸以下のマンション）、 50 戸を超える ものは 353 千円/戸で、この「戸当り限度額に戸数を乗じた総額の $2 / 3$ が補助対象の上限」とされている。建替え決議後の調查設計計 画費等に対する補助の基䃈的要件として、「市街地総合再生計画等の 区域内の事業又は市街地整備事業に寄与寸る一定の事業」、「建替え 前の建築物が区分所有者数 10 人以上で、法定耐用年数(鉄筋コンク リート造では 47 年)の $1 / 2$ を経過していること(被災等により建物に 機能の低下を生じている場合も含む)」、建替え後の建築物は $1 / 2$ 以 上を住宅とし、建替え前の戸数や延べ面積以上の住宅を供給するこ と」、「建替え決議等がなされていること」が求められている。

補助の対象となるものは、「調査設計計画費（事業計画策定費、地 盤調查費、建築設計費) 、「土地整備費（建築物除却費、整地費、補 償費)」、「共同施設整備費（空地整備費(通路、駐車施設、緑地等)）、 「供給処理施設整備費(給水施設、排水施設、電気施設、ガス施設、 電話施設、ごみ処理施設、情報通信施設、熱供給施設)」、その他共 同施設整備費、立体的遊歩道 -人工地盤等、電気室・機械室、共用 通行部分(廊下など)、駐車場、生活基盤施設(集会所など)、高齢者 生活支援施設、備蓄倉庫・耐震性貯水槽、防音・防振工事費等で、 多くの工事が補助対象となっている。また、補助率は当該工事費の $2 / 3$ 以内(国 1/3 以内、公共団体 $1 / 3$ 以内)で、合計寸ると相当の補助 金額となることが推測できる。

\section{2 ) 都市再生住宅制度}

この制度は、「マンション建替事業等の施行により住宅を失い住宅 等に困窮することとなる従前居住者のために住宅を整備・供給する 事業に対して、その費用の一部を助成する制度」で、従前のマンシ ヨンから退去せざるを得ない居住者に対する救済支援といえる。 対象となるマンション建替えの要件として、「円滑化法に規定する
マンション建替事業で以下の要件を満たすもの又は同法に基づき建 替えの勧告を受けたマンションの建替え」で、対象地域として「都 市再開発法第 2 条の 3 第 1 項に規定する計画的な再開発が必要な市 街地(1 号市街地) のうち特に一体的かつ総合的に市街地の再開発を 促進すべき相当規模の地区 $(2$ 号地区) の区域内、又は、都市再開発 法第 2 条の 3 第 2 項に規定する計画的な再開発が必要な市街地のう ち特に一体的かつ総合的に市街地の再開発を促進すべき相当規模の 地区(2 項地区)の区域内に施行マンションの敷地が存在する」で、主 に「地区面積 $1,500 \mathrm{~m}^{2}$ 以上」、「従前住宅戸数 50 戸以上」、「耐用年 数の $2 / 3$ を経過」したものとされている。

住宅の供給方式としては、(1)民間建設・管理方式 (民間が建設し、 民間が管理することにより供給する方式) (2)民間住宅借上方式（地 方公共団体が民間住宅を借り上げることにより供給する方式）(3)直 接建設方式（地方公共団体が直接建設を行うことにより供給する方 式）がある。補助金の補助率は、「民間建設・管理方式及び民間住宅 借上方式」の場合、共同施設整備費補助として国 $1 / 3$ 公共団体 $1 / 3$ と、家賃対策補助として国 $1 / 2$ 公共団体 $1 / 2$ がある。「直接建設方式」 の場合、建設費補助として国 1/2、また、家貨対策補助も国 $1 / 2$ と されている。

この制度の目的は、マンションの建替えに際して、やむを得ずそ のマンションから退去する必要がある従前居住者に対する救済策で あり、当該マンションそのものの建替えに対する支援とはならない が、ある意味間接的な支援策であると考えられる。ただ、(1)民間建 設・管理方式や(3)直接建設方式が、実際に上手く機能するかどうか は疑問が残る。(2)民間住宅借上方式の場合は、公営住宅としての位 置づけになると考えられる。そうであれば、都市再生住宅制度を、 従前のマンション建替え後の住戸に適用寸ることも一つの考え方と 思われる。つまり、買取り請求等によって退去せざるを得ない従前 居住者を建替え後の住戸に継続して居住可能とする方策を検討する 必要があるのではないかと考える。

\section{3)（独）住宅金融支援機構によるまちづくり融資制度}

この制度は、「事業の構想・計画段階から資金計画の相談や建設資 金を融資・建設資金融資の対象としては建築工事費の他に、調查設 計計画費、補償費、土地取得費、除却工事費も融資の対象」となる 融資制度である。

また、融資の対象となる条件として「建築物の地上階数が 3 階以 上であること」、「建築物の敷地面積が $300 \mathrm{~m}^{2}$ 以上(マンション建替 え円滑化法に基づく事業以外の事業の場合は、建築物の敷地面積が $500 \mathrm{~m}^{2}$ 以上であること)であること」、「建替え前の区分所有建築物が

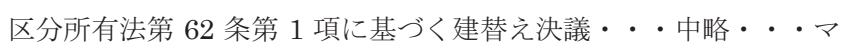
ンション建替え円滑化法第 108 条第 1 項に基づくマンション敷地売 却決議を行っていること」及び建替え前の建築物が「減価償却資産 の耐用年数等に関する省令に定める耐用年数の 3 分の 1 以上を経過 していること」としている。この制度の特徴は、マンション建替計 画の策定に必要となる調查設計費といった初期段階から融資を受け ることができ、また、あらたな建築物に対する融資だけではなく、 既存建物の除却費用の融資も受けることができるというもので、マ ンションの建替えにとって有効な融資制度だといえる。

\section{2 不動産信託によるマンション建替えと経営}


不動産信託を活用する区分所有マンションの建替えの基本的な仕 組みを以下に示寸 (図 3)。

1 ） 区分所有者による非営利型一般社団法人を設立し、区分所有者 は社団法人の社員となる。

2 ) 一般社団法人は、区分所有者（社員）と信託契約（限定責任信 託注2)）を締結・信託登記を行い、すべての区分所有権は受託者 となる一般社団法人に移され、土地建物の不動産は一般社団法人 が所有する。区分所有者は委託者兼受益者として受益権を取得す るともに、建替え後に賃借人へと移行する。

3) 受益者は、土地受益権と永続居住権を取得する。土地受益権は 居住する権利として建設後 30 年間で償却し、30 年未満で当該居 住者が退去もしくは死亡する場合、一般社団法人が土地受益権を 買取り・清算し、残余分は本人もしくは親族等に返還される。

当該居住者が 30 年を超えて居住する場合、土地受益権は消滅 するが永続居住権は本人が退去もしくは死亡する時点まで存続す

る。また、永続居住権は相続の対象にならないものとする。

4) 一般社団法人は、従前の区分所有者等（社員）によって組織さ れ、その中から選出される理事で構成される理事会によって運営 される。また、理事会から提案される議案等は、賃借人（受益者 を含む) による社員集会（受益者集会）等で議決される。

5 ）一般社団法人が、建設工事等の資金借入れを行ない、建替え工 事を発注・実行する。一般社団法人は建替え事業費に対して、公 的な資金補助を受け、住宅金融支援機構等から借入れを行なう。

6 ）建物完成後、一般社団法人は受託者として継続して土地建物を 所有・経営する。従前の区分居住者は受益権に基づき、賃借人（社 員）として比較的安価な家貨設定で継続居住する。

7 ）一般社団法人が清算、買取った住戸は、あらたに賃貸物件とし て一般の第三者に貸し出される。その場合、新たな賃借人は一般 社団法人の社員となる。新たに生じる賃貸期間は、新築建物の使 用年数を 70 年、建替え時の居住者年齢を 60 才としその平均寿命 を 90 才と仮定すると 40 年となり、一般社団法人は従前居住者退 去後の約 40 年間、当該住戸を賃貸することで賃料収入を得る。

8 ）すべての受益者（従前区分所有者）が退去もしくは死亡した場 合、一般社団法人は寸べての受益権を取得する。したがって、信 託法第 163 条 2 項（受託者が受益権の全部を固有財産で有する状 態が一年間継続したとき）の規定によって、信託は清算・終了す るが、信託終了後も一般社団法人は継続し、当該社団法人の社員 となる新たな賃借人と彼らから選出される理事及び理事会によっ て、当該住宅は継続して管理・経営される。

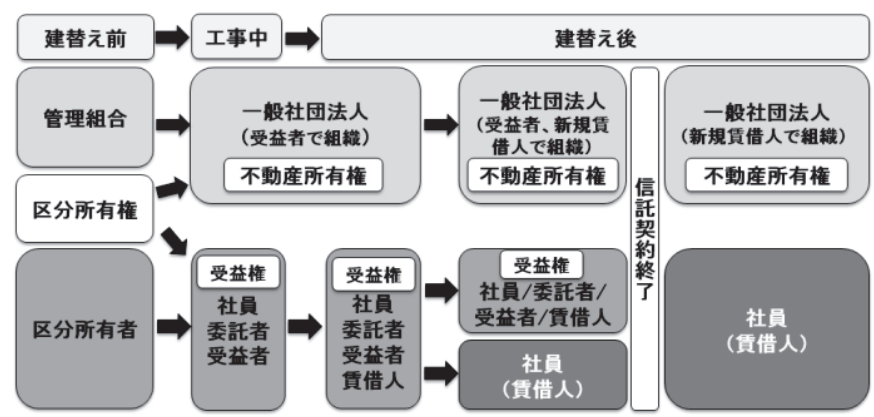

図 3 不動産信託による組織及び建替えの基本スキーム

\subsection{1 区分所有者全員が貨借人となる合意をした建替えの場合}

区分所有者の全員が信託契約・区分所有権を信託登記し、建替え 工事完了後も社員・委託者兼受益者・賃借人となる場合は、図 3 の とおりとなる。この場合、区分所有権は受託者である一般社団法人 にすべて移行し、区分所有建物ではなくなる。また、受益者が死亡 もしくは退去する時点で、当該信託財産は一般社団法人によって買 取り・清算される。そして、当該住戸は賃貸化され、長期的にみれ ばすべての居住者が新規賃借人となり、一般社団法人が不動産のす べてを所有する賃貸住宅となる。

\subsection{2 区分所有権と信託が混在する建替えの場合}

信託によって建替えを行なうが、完成後に区分所有権と信託が混 在する場合は、まず区分所有者の全員が一般社団法人の社員となっ て信託契約・区分所有権を信託登記し、建替える。建替え完了後に、 再び区分所有マンションに移行し、管理組合が設立される。そして、 従前の一般社団法人は、議決権を持つ区分所有者の一員となる。一 般社団法人の社員であることを望む者は、社員・委託者兼受益者・ 賃借人として継続居住する（図 4)。ただ、この場合の一般社団法人 は、社員である従前区分所有者の区分所有権を持つ区分所有者の一 員となるため、信託に参加しない他の区分所有者の比率が高くなる。 したがって、区分所有者及び議決権（区分所有法第三十九条）によ る決議の衡平性についての検討課題が残るといえる。

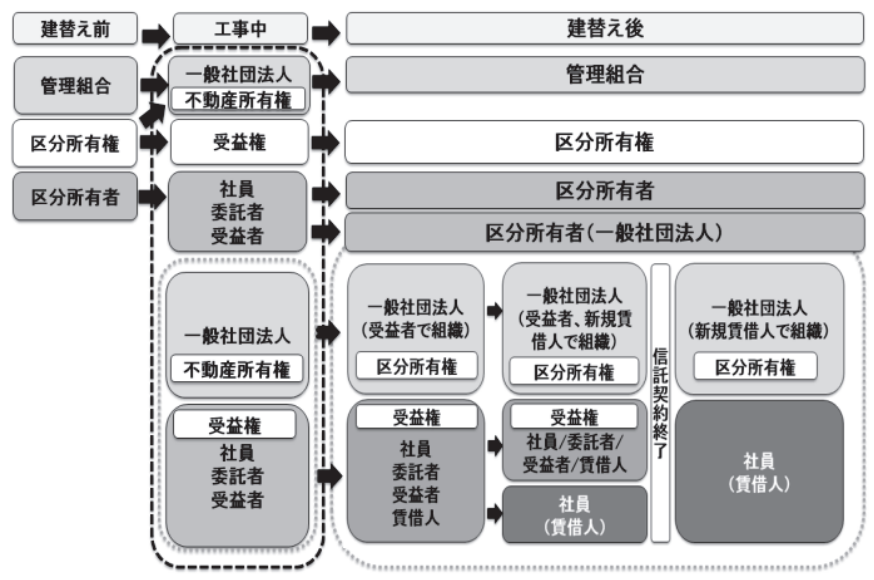

図 4 区分所有権と不動産信託が混在するスキーム

\section{4. マンション建替え事業のプロジェクトファイナンス}

信託による建替えでも、区分所有者の費用負担の課題は残る。そ のため、公的支援を受けて初期投資を抑えた建替え事業のプロジェ クトファイナンス注3)（以下、ファイナンスとする）のシミュレー ションを行う。マンション建替え事業において公的支援を行う必要 性、基本的な考え方として、次の 4 点があげられる。

1 ) 住宅ストックとしてのマンションの特殊性

マンションは、住宅ストックとしてのボリュームが巨大で、老朽 化し放置されることによる社会的な影響は大きい。また、マンショ ンは広い敷地を所有・管理しており、敷地内インフラ設備などの維 持管理は管理組合によって行われている。これらの維持管理に関わ る行政コストは戸建て住宅より低いため、マンション居住を支える ことは行政にとってもそのメリットは大きい。 


\section{2 ）経済的理由による不本意退去を防ぐ}

建替え決議によって、退去を余儀なくされる区分所有者の中で、 その場所での居住を望みながら、経済的な理由で建替え事業に参画 できない者に対して、建替え後も住む続けられる方策を検討すべき だと考える。その意味で、民間住宅借上方式を活用する都市再生住 宅制度の見直しで、建替え後の住宅に継続居住できる方式、建替え 後住戸の一部を公営住宅として活用する方法も検討する必要がある。

\section{3）建替え費用負担等の低減と公的資金支援の再活用}

マンションの構造は、 $\mathrm{RC}$ 造もしくは SRC 造となるため、基本的 に工事期間が長く、建物解体費、建築工事費等も割高となる。した がって、毎月の返済額を抑えるには借入れ資金の総額を抑えること が重要となり、優良建築物等整備事業のような公的資金の導入も必 要といえる。ただ、現在の優良建築物等整備事業(マンション建替夕 イプ)における補助は給付型であるため、財政面からいってその普及 と継続性に疑問が残る。長期的な支援制度の維持を勘案すれば、給 付型ではなく、むしろ無利子の長期借入金とするのが望ましいと考 える。そして、この公的資金補助は、借入れた住宅ローン完済後の 賃料収入から返済することにすれば、返済される資金を再び他のマ ンション建替えの資金補助の原資とすることも可能となる。

\section{4 ) 持続可能な居住システムの可能性}

また、建替え後の住宅ローンや公的資金の返済後に生じる余剩金 は、将来のリノベーション費用や当該建物の建替え費用、また、他 のマンションの建替えに対する公的な資金補助としての活用も考え られる。このことで、長期的かつ持続可能な集合住宅の居住システ ムの展望が見えてくるのではないかと考える。

4. 1 Tコーポ (大阪市) による建替えシミュレーション

1969 年に建設された T コーポにおいて、一般社団法人を設立し て建替えを行ない、建替え完了後も区分所有者の全員が委託者兼受 益者兼賃借人となる建替え事業費等の考察を行う。建物の与条件を、

1 ) 従前と同等の住戸数で建替え

2) 間取り、基本性能や設備水準等は建替え前と同等程度

3 ）エレベーターの設置による床面積の増加

4）建替え後の建物の耐用年数を 70 年 とする。

表 1 丁 コーポ建替え計画概要

\begin{tabular}{|l|r|r|}
\hline & \multicolumn{1}{|c|}{ 建替え前 } & \multicolumn{1}{c|}{ 建替え後 } \\
\hline 敷地面積 $\left(\mathrm{m}^{2}\right)$ & 2,000 & 2,000 \\
\hline 容積率 $(\%)$ & 300 & 300 \\
\hline 延べ面積 $\left(\mathrm{m}^{2}\right)$ & 4,300 & 4,760 \\
\hline 専有延べ面積 $\left(\mathrm{m}^{2}\right)$ & 3,900 & 3,900 \\
\hline 住戸数 $($ 戸 $)$ & 65 & 65 \\
\hline 戸当り専有面積 $\left(\mathrm{m}^{2}\right)$ & 60 & 60 \\
\hline 構造·規模 & RC造·5階建 & \multicolumn{1}{|c|}{ RC造·5階建 } \\
\hline エレベータ一 & 無 & 有 \\
\hline
\end{tabular}

現在、Tコーポはエレベーターがない $6 つ$ 階段室をもつ階段室 型住棟であるため、建替えに際してはあらたにエレベーター1 台と 2 つの階段室で計画した。建替え後の面積は、エレベーターとそれ に伴う 1 階エレベーターホール、各階エレベーターホール及び廊下 面積の増加と従前の階段室面積の減少等を勘案して算出した (表 1 )。

\section{1.1 建替え事業費の算定}

事業資金計画の費目については、円滑化法の建替え組合設立認可 申請の事業資金計画の支出項目注4) を参考にした。調查・設計・計 画費用として 9,020 万円、既存建物解体費及び整地費として 7,582 万円、建物建設費及び付帯工事費として 105,900 万円、事務費 2,056 万円、建設関係費用を合計した総額は 124,559 万円で、 1 住戸当り の負担額は 1,916 万円となった。また、工事中の仮住居費用 202 万 円及び引越し費用 30 万円を加えると、1 住戸当りの総事業費の負 担額は 2,149 万円となった（表 2 )。

なお、仮に $\mathrm{T}$ コーポの建替えに、優良建築物等整備事業(マンショ ン建替タイプ)を活用した場合のおおよその補助金額を試算する。試 算の条件として、補助対象となる共用部の延べ面積を全体延べ面積 の $15 \%$ （レンタブル比 $85 \%$ ） と仮定し、補助対象となる建築工事 費を建築工事費全体の $15 \%$ とする。また工事費のうち、その他工事 費は寸べて補助対象と仮定する。表 2 の項目における試算でのおお よその補助金額は、

1 ） 6,013 万円（調查設計計画費の $2 / 3$ )

2 ） 5,055 万円（土地整備費の $2 / 3$ )

3 ） 10,282 万円（建築工事費の $15 \%$ の $2 / 3$ )

4）2,056 万円（その他工事費の 2 /3)

補助金の総額は 23,406 万円で、戸当り約 360 万円となった。

T コーポを建替える場合、現行制度においても相当額の補助金が あることがわかる。しかも、当該補助金は給付型で返済義務はない。

\section{表 2 Tコーポ建替え事業資金計画 （単位：万円）}

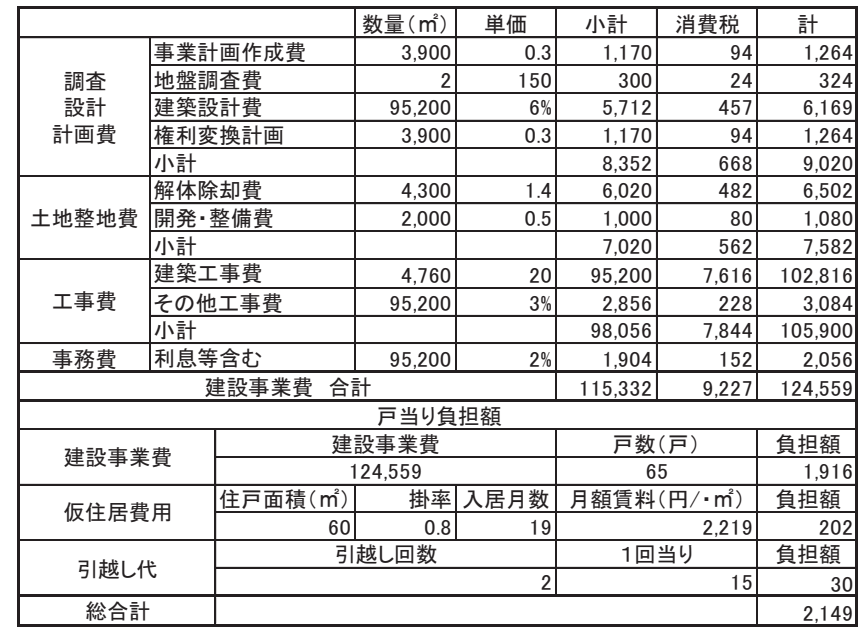

\subsection{2 建替え後の家賃と建替え事業のファイナンス}

$\mathrm{T}$ コーポと同程度の住戸面積の近傍賃貸マンションの現状家賃と

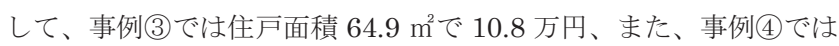
61.0 m² 8.5 万円であった（表 3 )。

表 3 Tコーポ近傍賃貸マンションの家賃（単位：万円）

\begin{tabular}{|c|r|r|r|r|r|r|c|}
\hline No & 間取り & 面積 $\left(\mathrm{m}^{2}\right)$ & 賃料 & 管理費 & \multicolumn{1}{|c|}{ 計 } & 単価 $\left(\mathrm{m} / \mathrm{m}^{2}\right)$ & 備考 \\
\hline (1) & $2 \mathrm{LDK}$ & 56.0 & 8.5 & 0.8 & 9.3 & 1,661 & 築15年、8階 /8階建 \\
\hline (2) & $3 \mathrm{LDK}$ & 70.0 & 8.8 & 0.6 & 9.5 & 1,350 & 築18年、2階 / 14階建 \\
\hline (3) & $3 \mathrm{LDK}$ & 64.9 & 10.1 & 0.6 & 10.8 & 1,656 & 築18年、4階 /14階建 \\
\hline (4) & $3 \mathrm{DK}$ & 61.0 & 8.1 & 0.4 & 8.5 & 1,390 & 築27年、4階/11階建 \\
\hline
\end{tabular}


その他、建替え事業における与条件は下記のとおりとする(表 4)。 1 ) 住戸当りの事業総額を 2,149 万円とする (仮住居費用等を含む) 2 ) 住戸当りの公的資金支援は、土地持分の実勢価額 615 万円の無 利子融資とし、返済期間は建替え後 35 年から 50 年の間とする 3 ) 住宅ローンはフラット 35 とし、借入金額 1,534 万円、借入金 利 $1.67 \%$ 、返済期間 35 年で住戸当りの月額返済は 4.9 万円注5)

4 ）建替え後の家賃は、近傍賃貸マンションの家賃と同程度の 9.1 万円と設定する（管理費月額 1 万円、修繥積立金月額 1.3 万円、 固定資産税及び都市計画税月額 1.9 万円注 6)、ローン返済分月額 4.9 万円)、なお、修繥積立金は、国土交通省のガイドラインの専 有延床面積 $5,000 \mathrm{~m}^{2}$ 未満の場合、 218 円 $/ \mathrm{m}^{2}$ ・月を参考に算出

5 ）物価上昇による家賃上昇などは考慮しない

6 ) 固定資産評価額の低減は考慮しない。

7 ）修繥積立金の金額を超える大規模修繥工事は考慮しない

原則として、受益者兼賃借人は 60 歳で建替え、以後の平均居住 年数を 30 年間とし、本人が希望する限り居住する権利があるも のとする。当該居住者は、月額 9.1 万円の家賃を負担するが、そ のうちの住宅ローン返済分は 4.9 万円となる（表 4 )

\section{表 4 家賃の算定}

\begin{tabular}{|c|c|c|}
\hline \multicolumn{2}{|l|}{ 家賃算定の条件と算定 } & 備考 \\
\hline 住戸当り総事業費(万円/住戸) & 2,149 & 1. 1住戸当りの建設費に対する公的な \\
\hline 住戸当り補助金額 (万円/住戸) & 615 & 補助金額は、615万円 (無利子、建替え \\
\hline 住戸当り借入金額 (万円/住戸) & 1,534 & 35 年後から 50 年間で返済)とする \\
\hline 住宅ローン(フラット35)返済期間(年) & 35 & 2. 受益者兼賃借人の居住する期間は、 \\
\hline 往宅ローン借入金利 (\%) & $1.67 \%$ & 建替え後の 30 年間とする(但し、本人が \\
\hline 住宅ローン返済額 (万円/月·住戸) & 4.9 & 希望するまで入居可能） \\
\hline & & 3. 受益権消滅後の新規の賃借期間は、 \\
\hline 家負の算定（万円/月・住戸） & 9.1 & 建替え 30 年後から 70 年後までの 40 年間 \\
\hline 1. 住宅ローン返済 & 4.9 & 4. 1 住戸当りの総事業費には、住民の \\
\hline 2. 管理費 & 1.0 & 引越し費用、工事中の仮住居の家賃を \\
\hline 3. 修績積立金 & 1.3 & 含む \\
\hline 4. 固定資産税＋都市計画税 (万円/月·住戸) & 1.9 & 5. 固定資産税の対象となる 1 住戸当りの \\
\hline 1)固定資産税（取引価額の70\%、税率1.4\%) & & 建物取得価額は既存建物解体費·土地 \\
\hline (1)土地 $($ 万円/年·住戸 $)$ & 1 & 整地費を除いている \\
\hline (2)建物 (万円/年·住戸) & 17.4 & 6. 家賃の構成は、 \\
\hline 2)都市計画税(取引価額の70\%、税率 $0.3 \%$ ) & & 住宅ローン返済＋管理費＋修繥積立金 \\
\hline (1)土地 (万円/年·住戸) & 0.4 & +固定資産税＋都市計画税とする \\
\hline (2)建物 (万円/年·住戸) & 3.7 & 7. 住戸当り延べ面積は共用部も含む \\
\hline 5. 固定資産算定基準 & & \\
\hline (1)住戸当り土地面積 $\left(\mathrm{m}^{2} /\right.$ 住戸 $)$ & 30.8 & \\
\hline (2)土地価額 $\left(\right.$ 万円 $\left./ \mathrm{m}^{2}\right)$ & 20.0 & \\
\hline 3)土地価額 (万円/住戸) & 615 & \\
\hline (4)建物取得価額 (万円/住戸) & 1,768 & \\
\hline 5)住戸当り延べ面積 $\left(\mathrm{m}^{2} /\right.$ 住戸 $)$ & 73.2 & \\
\hline
\end{tabular}

図 5 は、建替え後の住宅ローン、公的資金の返済額及び返済後の 積立金の推移を表している。当該居住者の退去後は、40 年間新たに 賃貸住宅として、月額 9.1 万円で一般に賃貸される。

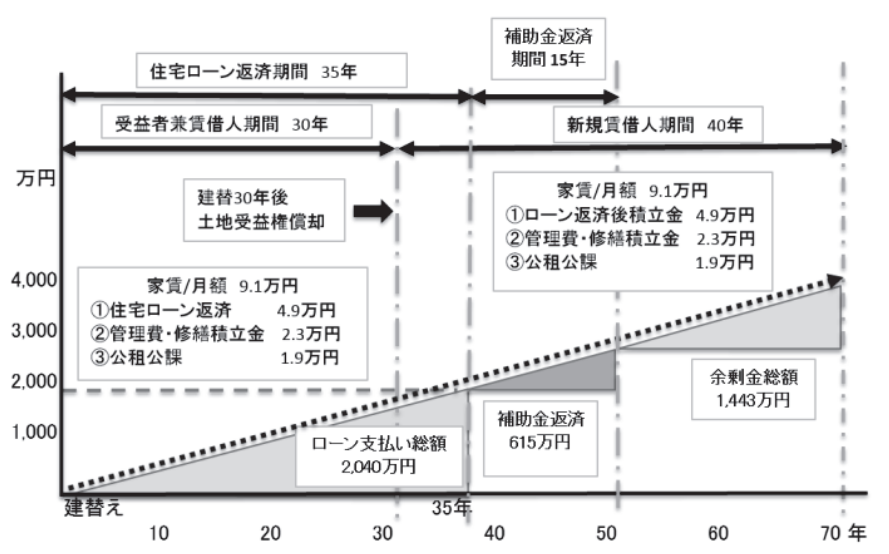

図 5 住宅ローン返済、補助金返済と余㮃積立金
建替え後、受益者兼賃借人の住宅ローン支払い期間は 30 年とし、 以後の 5 年間は新たな賃借人の家賃の中から住宅ローンが返済され る。また、住宅ローン完済後からの 15 年間で、支援された公的資 金 615 万円が返済される。さらに、住宅ローン及び公的資金の完済 後における家貨に含まれる住宅ローン返済分相当の余剩金総額 1,443 万円は、将来的な資金として積夕立てられる（図 5 )。

建替え事業のファイナンスは、公的資金（無利子、建替え後 35 年から 50 年の間で返済）と市中借入金で賄われるが、市中借入金 に対して、行政等による政策的な債務保証をすることも考えられる。 また、受益者が建替え後 30 年未満で退去する場合、一般社団法人 がその土地受益権を買取り・清算するが、そのための資金は、一般 社団法人の積立金や市中借入金もしくは公的な資金支援等で賄うこ とになる。なお、土地受益権は建替え時の敷地割合分の土地実勢価 額から仮住居費用と引越し費用を除いた額とし、建替え後 30 年で 償却するものとする。 $\mathrm{T}$ コーポの場合、土地受益権は住戸当り 383 万円（土地実勢価額 615 万円-仮住居費用 202 万円-引越し費用 30 万円）となる。

\section{5. まとめ}

1) 2015 年 4 月現在における円滑法以外のマンションの建替え及 び建替え工事中事例は 155 事例で、円滑法による建替え事例が 67 事例あった。建替え後の住戸数増加の平均は、円滑化法以外の建 替えでは約 1.92 倍、円滑化法による建替えでは約 1.74 倍であっ た。また、建替え後の住戸数の増加が少ないものの多くは、優良 建築物等整備事業等の複合商業施設での建替えや計画道路に伴う 移転補償での建替え事業、土地区画整理事業など特殊な要因によ るものが多い。したがって、従来の一般的なマンション建替えは、 余剩容積を活用寸る等工事費負担を少なくした方法だといえる。

2) マンション建替えの選択肢の一つとして、非営利型一般社団法 人が建替え、区分所有者は一般社団法人の社員となり、受益権を 持った賃借人として建替え後のマンションに永続居住できる方式 である。これは特に、建替え費用負担が困難な区分所有者にとっ て、メリットがある。

また、一般社団法人が、信託受託者として不動産を所有・管理 する形態であるため、信託の特徴である、

(1)万一受益者が死亡した場合においても、当初の信託契約が継続 される、財産の長期的管理機能としての「意思凍結機能」

(2)財産の管理・運用の一元化が可能な「財産の集団的管理機能」 (3)万一、一般社団法人が破産した場合であっても、土地及び建物 の信託財産が保全される「倒産隔離機能」等によって、有効な不 動産管理が可能になると考えられる。

3 ）マンション建替に対する公的支援として、優良建築物等整備事 業(マンション建替タイプ)の資金補助があり、 $\mathrm{T}$ コーポにおける 試算では、戸当り約 360 万円の補助を受けることができる。した がって、T コーポ建替え事業における土地持分の実勢価額である 戸当り 615 万円の公的支援との差額は、 255 万円程度である。た だ、優良建築物等整備事業は資金補助であり、本試算における公 的資金支援は、無利子ではあるものの返済義務のある融資として いる。さらに、建替えマンションからの退去を余儀なくされる居 住者のセイフティネットとして民間住宅借上等の都市再生住宅制 
度がある。現在、この制度は円滑化法に規定するマンション建替 事業であること等の条件があるが、マンション建替え後の住戸に 対する民間住宅借上制度注7) の検討も必要と思われる。また、本 方式によるマンションの建替えは、区分所有のマンションから賃 貸住宅に移行するため、将来的に空き住戸が生じる恐れは残る。

したがって、公的支援を受ける条件として、建替え後の空き住 戸の一定数や将来的な空き住戸を自治体による優先的な借上住宅 として公営住宅化を図る等、空室を生じさせない仕組みづくりも 検討する必要がある。

4） T コーポ建替え事業の試算では、建替え工事費だけではなく、 引越し費用や仮住まいの居住費といった費用負担を、建替え後の 住宅の家賃という形で返済することとした。そして、家賃は近隣 相場とほぼ同一の月額家貨を 9.1 万円と寸るが、その中には、管 理費・修繥積立金及び固定資産税分の 4.2 万円が含まれている。 したがって、一般の分譲マンションのように適切な維持管理が可 能となる。そして、個人が支払う実質的な住宅ローンの返済額は 4.9 万円/月で、戸当りの事業総額である 2,159 万円を借入れた場 合の毎月返済額 6.8 万円注5) より約 2 万円低く抑えることができ る。また、公的補助金の返済後から建設後 70 年までの間で、約 1,443 万円の積立金が生まれる。この積立金の一部を当該建物の 維持費用だけではなく、他のマンション建替え費用に使用する等、 新たな形での活用も期待できる。

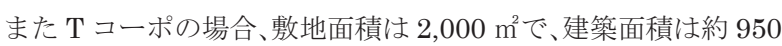
$\mathrm{m}^{2}$ 程度と計算できる。したがって、建蔽率が $50 \%$ 以下にとどまり、 従前オープンスペースの確保も可能で、近傍マンションとの比較 においても居住環境面での差別化を図ることができる。また、一 定数の自走式駐車場の設置も可能で、そこから生じる駐車場料金 を積立金として土地受益権の買取り資金や修繕積立金等にあてる ことも可能となる。

不動産を受益権としてもつ信託による建替えは、所有権意識が 強い日本においても、比較的受け入れやすい方式だと思われる。 また住戸数を増加させない建替えであり、オープンスペースを確 保することで、子供たちの遊び場等良好な居住環境も期待できる。

特に、老朽化や耐震性に劣る建替えニーズが高いマンションに おいて、費用負担の問題で建替え計画が停滞している場合に有効 となる。同時に、民間デベロッパーにとっても意義がある。建物 を作ることが彼らの主な業務であるため、人口減少によって空き 家が増加する状況にあっても、大量のマンションが供給され続け ている。新たに建てるのではなく、建替えニーズの高いマンショ ンの建替えを可能とすることで、人口減少時代の都市を形成する 重要な取組みとなる可能性がある。

今後の課題として、専門実務面での課題の抽出と考察が必要で、 (1)信託契約時における区分所有権と受益権との等価交換の妥当性 (2)非営利型社団法人の賃料収入や事業収入等の税務に関するもの (3)一般社団法人の事業・経営管理を支援する組織のあり方 (4)一般社団法人のあり方として、その健全な経営を図るための有 識者等も交えた組織構成及び運営方法 (5)信託法と区分所有法との調整及び今回の形式にあった新たな法 制度の可能性を探る、等の検討が必要だと考える。

\section{謝辞}

本研究は、日本学術振興会の科学研究費補助金、挑戦的萌芽研究 「NPO 法人による持続可能なマンション建替えシステムの研究」 による。この場をお借りして、同振興会に感謝申し上げます。

\section{参考文献}

1) 齊藤哲郎: 分譲マンション管理における信託活用の可能性について(第 1 回, 第 2 回),REITO NO.77,pp.38〜48,2010.4, RETIO NO.78,pp44〜52,2010. 7

2）鎌野那樹：マンションの「再生」と「解消」,アンケート調査・比較法を 踏まえての立法論覚書 (信託制度の導入等), 丸山英氣先生古稀記念論文集一 マンション学の構築と都市法の新展開, プログレス, pp. 67〜88,2009

3) マンション再生協議会 : 建替え事例,

http://m-saisei.info/tatekae/sonotajirei_index.html,（取得 2015.10.1）

4) 新井誠：信託法第 4 版,有斐閣, pp.86〜106,2014

5）国土交通省：マンション建替え実務マニュアル資料 2 建替え支援制度, http://www.mlit.go.jp/common/001064909.pdf，（参照 2016.1.21）

6）住宅金融支援機構 : フラット 35 , http://www.flat35com/simulation/simu_01.html，(取得 2016.1.11)

7) 辻壽一：人口減少時代とマンション建替え,マンション学第 53 号, pp. $18 \sim 32,2015.12$

8）国土交通省：マンションの修繥積立金に関するガイドライン, 2011.4

9）米田淳：不動産信託の活用術, 住宅新報社, 2008

10）米田淳：マンション建替えにおける不動産信託の可能性, マンション学 第 53 号, pp.33〜37,2015.12

11）国土交通省土地・水資源局：不動産管理信託の普及促進及び担い手拡大 に関する調査検討業務報告書, 2010.3

12）財団法人マンション管理センター：マンション管理の新たな枠組みづく りに関する調査検討報告書, 2008.3

13）国土交通省：多世代利用住宅に資する供給手法及び利用形態（組合所有 方式）関する調查検討資料 1-3-4,2009.10

注

注 1）一般社団法人とは，「一般社団法人及び一般財団法人に関する法律（平 成 18 年法律第 48 号) 」に基づいて設立された社団法人のことをいい、 設立の登記をすることによって成立する法人

注 2）「限定責任信託とは、受託者が当該信託のすべての信託財産責任負担 債務について信託財産に属する財産のみをもってその履行の責任を負う 信託」と定義されている(信託法 2 条 12 項)

注 3) プロジェクトファイナンスとは、特定のプロジェクトに対する融資で、 プロジェクトから生じる収益を資産価值とし、それを担保に融資される

注 4）国土交通省：マンション建替え実務マニュアル, 資料 $1, \mathrm{pp}$ 資 $74 \sim 75$, http://www.mlit.go.jp/common/001064908.pdf（参照 2016.1.21） (1)事業計画費: 建て替え事業計画作成費・建替え決議のための資料作成及 び建替え組合設立認可申請に要する費用(2)権利変換計画 : 各権利者の従前 従後の資産配置、権利調整、管理運営計画なども含む(3)事務費 : 建替え組 合（建替え事業を実施する組織）の事務手続き費用

注 5）住宅金融支援機構のフラット 35 のローンシミュレーションで試算 http://www.flat35.com/simulation/

注 6) 固定資産税と都市計画税（1.9 万円/住戸 - 月）

(1)土地価額 615 万円/住戸（土地面積 $30.8 \mathrm{~m}^{2} \times$ 土地価額 20 万円 $/ \mathrm{m}^{2}$ ) (2) 建物取得価額 1,768 万円/住戸 (事業費負担額 1,927 万円-土地整地費 127 万円-事務費 32 万円）(3)土地固定資産評価額：土地価額の $70 \%=431$ 万円(4)建物固定資産評価額 : 取得価額の $70 \%=1,238$ 万円(5)固定資産税 率 : $1.4 \%$ ( 都市計画税率 : $0.3 \%$ (7) 土地固定資産税 : 1.0 万円（小規模住 宅用地 $200 \mathrm{~m}^{2}$ 以下の評価額を $1 / 6$ に軽減寸る税制を適用) 88建物固定資 産税 : 17.3 万円 (7)土地都市計画税 : 0.4 万円 (小規模住宅用地 $200 \mathrm{~m}^{2}$ 以 下の評価額を $1 / 3$ に軽減する税制を適用) (8)建物都市計画税 : 3.7 万円

注 7）現在、大阪府貝塚市において、公営住宅の総量削減のためPFIによる 民間賃貸住宅の公営住宅化を計画している。貝塚市には、築 50 年超の 市営木造住宅が 500 戸以上あり、その居住者の多くが高㱓者である。「貝 塚市営住宅の有効活用による官民連携事業支援」によって、新たに公営 住宅を建てるのではなく、民間賃貸住宅を活用した公営住宅の仕組みを 検討中である。 


\section{BASIC STUDY OF HOW TO REBUILD A CONDOMINIUM \\ USING THE TRUST WITH PUBLIC SUBSIDES}

- Converting from the ownership to the use -

Toshikazu TSUJI* and Mai BABA**

* Prof., Osaka Shoin Women's University, Ph.D.

** Researcher, Hokkaido Research Organization, Dr.Eng.

The construction cost of a condominium is more expensive than a detached residence. Therefore, it is necessary to keep the condominium in a good condition and use it as long as possible. But someday it will be necessary to rebuild that condominium and we need to develop a new rebuilding system that the resident can agree to rebuild it by decreasing a financial burden of the residents. And for that aim, it is important to convert the rebuild one from the condominium to the rental apartment (from the ownership to the use).

The rebuilding by the general incorporated association as the civil trust can secure the continuity of the business and eliminate various risks under construction and manage the rebuilding housing. This system is basically not to increase the number of the dwelling units and also can keep the conventional open space. The support fund by the administration will be repaid and that repaid fund will be reused as the support for the rebuilding of another condominium. In addition to this, this system also will be able to make another fund support for the rebuilding of other condominium by using their own fund. The administration is also able to let this rental dwelling units have the function of the public housing and this will be the incentive to do a public support for a condominium rebuilding.

After rebuilding the condominium, it will be the nonprofit rental housing that the civil trust organization owns. And at time of the end of the trust, that organization will continue as the general incorporated association.

This system will be the independent sustainable housing system managed by the residents. 